\title{
INFLUENCE OF THE ESTROUS CYCLE ON SOME NON REPRODUCTIVE BEHAVIORS AND ON BRAIN MECHANISMS IN THE FEMALE RAT*
}

\author{
Adriana Silvia González JatufF ${ }^{* *}$, Mariana Torrecilla*** MarCela Quercetti****, \\ MARÍA PATRICIA ZAPATA ${ }^{* * * *}$, AND EdUARdO LUCIANO RodRígUeZ ECHANDía*****
}

\author{
*Supported by grants from Universidad Nacional de Cuyo (UNCuyo) and founds from the Consejo \\ Nacional de Investigaciones Científicas y Técnicas (CONICET), Argentina. \\ ${ }^{* *}$ Doctor in Biochemistry. Member of the Scientific Researcher Career of Consejo Nacional de \\ Investigaciones Científicas y Técnicas (CONICET). \\ ***Doctor in Psychology. Scholar post Doctoral of the Consejo Nacional de Investigaciones \\ Científicas y Técnicas (CONICET). E-Mail: mtorrecilla@mendoza-conicet.gov.ar \\ ${ }^{* * *}$ Degree in Biology. Área de Farmacología of the Facultad de Ciencias Médicas of the \\ Universidad Nacional de Cuyo (UNCuyo). \\ ${ }^{* * * * *}$ Member of Technichal Career of the Consejo Nacional de Investigaciones Científicas y \\ Técnicas (CONICET). \\ ****** Professor Emeritus of the Universidad Nacional de Cuyo (UNCuyo). \\ Instituto de Medicina y Biología Experimental de Cuyo (IMBECU - CONICET). \\ Área de Farmacología de la Facultad de Ciencias Médicas \\ Universidad Nacional de Cuyo (UNCuyo). \\ Avenida Ruíz Leal s/n. Parque General San Martín. (5500) Mendoza. República Argentina \\ The authors wish to thank $\mathrm{Dr}$. G. Jahn for the revision of the present manuscript.
}

\section{RESUMEN}

El rol de las hormonas sexuales sobre el comportamiento reproductivo ha sido extensamente documentado. La fluctuación periódica de hormonas sexuales en hembras de numerosas especies ha sido relacionada con cambios comportamentales no sexuales tales como humor, ansiedad, agresión y respuesta a estrés. El sustrato biológico-neural de estos cambios se basa en los cambios que estas hormonas inducen en el Sistema Nervioso Central. Este trabajo resume algunos cambios que afectan a receptores y neurotrasmisores de los sistemas GABAérgico, serotoninérgico, dopaminérgico y péptido liberador de prolactina del SNC de la rata. La rata hembra posee un ciclo sexual de 4 días de duración, denominado ciclo estrual. La presente revisión se informa en tres secciones. (1) Se presenta una breve descripción de la variación de tres hormonas sexuales principales con acción directa sobre el SNC: estrógenos (E2), progesterona (P4) y prolactina (PRL). Se han descripto propiedades ansiolíticas para P4 y anti-estrés para PRL; para E2, la bibliografía es controvertida, describiéndose acciones excitatorias y anti-estrés. (2) Se informan algunos cambios cerebrales y comportamentales que tienen lugar en cada estadio del ciclo estrual. Las fluctuaciones hormonales se consideran básicas para la interpretación de tales cambios. (3) Se mencionan algunos hallazgos acerca de la influencia hormonal cíclica sobre los sistemas de neurotransmisión del SNC y sobre un nuevo péptido propuesto como mediador de la respuesta a 
estrés, el péptido liberador de prolactina (PrRP). Esperamos que este trabajo contribuya a un mejor entendimiento de los mecanismos del comportamiento de las hembras y sus variaciones, y sus implicancias farmacológicas y diagnósticas.

Palabras clave: Ciclo estrual; Comportamiento no sexual; Rata; Hormonas; Mecanismos cerebrales.

\section{ABSTRACT}

Sex hormone fluctuations in females are involved in some behavioral states such as mood, anxiety, aggression and stress response, due to functional changes in the central nervous system (CNS) activity induced by the cyclic sex hormone fluctuation. This review includes three sections.

1.- A description of the three major hormone fluctuations in the estrous cycle: estrogens (E2), progesterone (P4) and prolactine (PRL). E2 achieves the maximum circulation levels during $P$. E2 is mainly excitatory and has been considered to have an antidepressive action. The highest plasma levels of $\mathrm{P} 4$ and its metabolite allopregnenolone (ALLO) occur in P. Ovulation takes place in the night of $\mathrm{P}$, and the resulting corpora lutea produces a secondary increase in P4 (and ALLO) on D. The P4 peak level occurring in D1 and in the evening of $\mathrm{P}$ was shown to exert benzodiazepine-like effects, including sedation. It has been proposed that ALLO, rather than P4 is the one acting on GABA systems. Circulating levels of ALLO parallel those of $\mathrm{P} 4$ across the estrous cycle and is known to have anxiolytic properties.

PRL is produced mainly in the adenohypophysis, though synthesis in other sites of the brain also occurs. Its regulation is mostly inhibitory and is exerted by dopamine (DA) released in the hypothalamus. A surge in PRL secretion occurs during P. PRL would be a modulator of the HPA-axis, and is considered as a stress hormone.

2.- Some behavioral and neural changes occur at each stage of the cycle. Lower anxiety level in $\mathrm{P}$ females was described. This has been correlated with increased circulating levels of endogenous ALLO in P. PRL is another hormone that may cause the lower scores of anxiety observed at $\mathrm{P}$, since the peak of plasma PRL is observed at this stage. A novel peptide, the Prolactin Releasing Peptide (PrRP), which is sensitive to E2 fluctuation, has also been linked to the lower activity of the HPA axis. Stress-induced activation of PrRP neurons is significantly decreased in E compared with $\mathrm{P}$ and $\mathrm{D}$, suggesting that E2 suppresses the activation of PrRP neurons. The late luteal phase (D) correlates with the premenstrual phase in women, commonly associated with psychological disturbances, including mood disorders and increased aggression. Consistently, increased levels of anxiety and aggression have been detected in rats during D.

3.- Findings about cyclic hormone influences on the CNS neurotransmitters and on the stress mediator, prolactine-releasing peptide (PrRP) were described. GABA is the main inhibitory system in the brain. Estrous-cycle-dependent increases in $\delta$-GABA $\mathrm{GA}_{\mathrm{A}}$ receptors were reported; this subtype underlying a tonic inhibitory current, is the most sensitive target of P4 and ALLO. E2 causes a reduction in GABAergic inhibition, leading to an increase in the excitatory tone. It also acts on hippocampus causing a transient lowering of GABA synthesis in the interneuron. These findings suggest an excitatory role for E2 through inhibition of the GABA system. The serotonin system, involved in behavioral responses such as stress, anxiety and depression, also exhibits variations along the estrous cycle, in part dependant of GABA-receptor changes.

Gender differences were described for DA function in the brain, due to E2 and P4 modulation. DA release and reuptake fluctuate with changes in circulating steroid levels. E2 enhances DA release and DA-mediated behaviors, such as general activity stimulation, food seeking behavior and sexual motivation. PrRP is produced in hypothalamic and extra hypothalamic structures. It has been proposed as a mediator of stress responses. Though gender differences have been shown, distribution of PrRP does not change during the estrous cycle.

We hope this review may contribute to understand the mechanism of female behavioral variations and their pharmacological and diagnostic implications.

Key words: Estrous cycle; Non sexual behaviour; Rats; Hormone; Brain mechanisms. 


\section{INTRODUCTION}

Behavioral responses in animals depend on external stimuli (experience) and endogenous factors. Age, gender and physiological state such as sexual receptivity, pregnancy or lactation are among the main sources of normal behavioral variations. In the majority of these situations, a particular hormonal profile underlie the changes in behavior; hormones modulate many brain receptors, their signaling mechanisms and neurotransmitter metabolism, thus inducing changes in neural transmission and in synaptic and neural plasticity. In this review we will focus on sexual hormones, particularly three hormones of the cycling female rat that influence emotional and cognitive functions, exceeding their endocrine reproductive role: Estrogens (E2), Progesterone (P4) and Prolactin (PRL). The role of these hormones on reproductive behavior has been extensively studied. We will consider only non reproductive behavioral aspects, through the sex hormone modulation of GABAergic, serotonergic, dopaminergic and prolacting-releasing peptide systems of the brain.

Female rats exhibit a short estrous cycle, compared to other mammals, including humans, lasting four or five days. The four-day cycle is the most frequent one, consisting in Proestrus (P), Estrus (E), Metaestrus or Diestrus 1 (D1), and Diestrus 2 (D2) that are characterized by specific variations in circulating hormones. Ovulation and sexual receptivity in rats take place in the night between $\mathrm{P}$ and $\mathrm{E}$. In the present review we will describe some of the brain changes that occur in each stage of the cycle and the changes in some of the main neurotransmitter systems. We will also focus our attention on the modulation of the stress response, a complex feature with emotional, behavioral, physiological and endocrine implications. Behavioral response to stress may be either active (the fight or fly reaction) or passive (freezing reaction); therefore, both excitatory and inhibitory neural pathways are involved. The hypothalamic-pituitary-adrenal axis (HPA), considered as the main endocrine system modulating stress responses, is specially considered in this review.

\section{Fluctuations in E2, P4 and PRL levels}

Increasing number of reports are concerned with the cyclic fluctuations of the main ovarian hormones, i.e. estrogen (17 $\beta$-estradiol , E2) and progesterone (P4), and the pituitary peptide prolactin (PRL) in connection with the functional changes occurring in some of the central neurotransmitter systems. Some of the major behavioral changes associated with these hormones are summarized in Table 1.

E2 is produced by the ovarian follicles under the follicle-stimulating hormone (FSH) stimulus and achieves the maximum circulation levels during P. E2 is mainly excitatory, it enhances locomotion (Ogawa, Chan, Gustafsson, Korach, \& Pfaff, 2003) and reduces immobility time in the forced swim test (Walf \& Frye, 2005). In the forced swim test the subject is place in a transparent cylinder, filled with water up enough to prevent paws contact with the botton; inmobility is interpreted as a behavioral despair, and antidepressant treatments produces a shortening of this parameter (see González Jatuff, Berástegui, Rodríguez, \& Rodríguez Echandía, 1999). In this regard, E2 has been considered to have an antidepressive action (Walf \& Frye, 2005).

However, some studies devoted to E2 in rodents are contradictory, showing that $\mathrm{E} 2$ can facilitate, or disrupt, or have no effect on fear conditioning or other types of emotional learning (Toufexis, Myers, Bowser, \& Davis, 2007). According to these authors, these controversial responses may be due to the interacting effect of the two major intracellular E2 receptors: $\mathrm{ER} \alpha$ activation increases fear and anxiety behaviors, whereas ER $\beta$ activation reduces these emotional responses.

In rats the granulosa cells of the ovary secrete $\mathrm{P} 4$ at high levels on $\mathrm{P}$ prior to ovulation and following the peak levels of E2, under both FSH and LH stimulation (see Smith, Shen, Gong, \& Zhou, 2007). The highest steroid levels occur in the afternoon of $P$, when circulating levels of $\mathrm{P} 4$ and its metabolite allopregnenolone (ALLO) are elevated for 10$12 \mathrm{~h}$ (see Smith et al., 2007). Ovulation takes place on the night of $\mathrm{P}$, and the resulting corpora lutea produces a secondary increase in 
P4 (and ALLO) on the day of D1 and lasting until the morning of D2 (see Smith et al., 2007). A P4 peak level occurs in the morning of D1 and in the evening of P (Figueiredo, Dolgas, \& Herman, 2002). P4 has been shown to exert benzodiazepine-like effects, including sleep responses (Lancel, Faulhaber, Holsboer, \& Rupprecht, 1999). It has been proposed that ALLO, rather than P4 itself would be responsible of the action on the GABA system. Circulating levels of ALLO parallel those of P4 across the estrous cycle (see Smith et al., 2007). It is known that both P4 and ALLO have anxiolytic properties (Mora, Dussaubat, \& Díaz-Véliz, 1996; Laconi, Casteller, Gargiulo, Bregonzio, \& Cabrera, 2001).

PRL is produced mainly in the adenohypophysis, though synthesis in other sites, including brain, has also been described (Méndez, Cariño, \& Díaz, 2005; BenJonathan, LaPensee, C.R., \& LaPensee, E.W., 2008; Semprini, et al., 2009). Many neurotransmitters are involved in the control of pituitary PRL secretion; in contrast with the rest of the main pituitary hormones, its regulation is mostly inhibitory and is exerted by the neurotransmitter dopamine (DA) released into portal circulation by the dopaminergic neurons of the arcuate and periventricular nuclei of the hypothalamus. A surge in PRL secretion occurs during $\mathrm{P}$ with a peak at midafternoon, together with a decline in the pituitary (Furudate, Ashihara, \& Nakano, 1989). In some cases a secondary peak in serum PRL is observed in the afternoon of $E$, at the time where pituitary PRL content has increased gradually (Furudate et al., 1989). PRL secretion is thus regulated by different mechanisms in $\mathrm{P}$ and E. PRL has been proposed to play a role as a modulator of the HPA-axis, in the restoration of body homeostasis, and would have a putative anti-stress action (Fracchia, González Jatuff, \& Álvarez, 1992; Furudate et al., 1989; Torner, Toschi, Pohlinger, Landgraf, \& Neumann, 2001). PRL is considered as a stress hormone, since exposure to acute stress induces a rapid increase in its plasma levels. The PRL response is distinct for different type of stressors, since ether anesthesia stress had no effect on the PRL surge observed in $\mathrm{P}$, while restraint enhanced it (Furudate et al., 1989). Nevertheless, it has been pointed out that the stress-induced PRL surge seems to take place by a mechanism other than the cyclic surge (Poletini, Szawka, Franci, \& Anselmo-Franci, 2006). Prolactinreleasing peptide (PrRP) has been proposed as a novel stress mediator in the central nervous system (Maruyama, Matsumoto, Fujiwara et al., 2001), modulating the HPA-axis, with gender-related differences in the rat brain (Adachi et al., 2005; Tóth et al., 2008).

The fluctuations of sex hormones are dynamic processes, increasing and decreasing at different rates and moments; so are cyclic changes in the central nervous system. The behavioral effects of these hormones, therefore, are hard to handle in intact animals. To characterize behavioral actions the ovariectomized rat model with steroid replacement is often used. Generally treatment regimes with E2, P4 and combinations of both are used, so as to mimick the stages of the estrous cycle or to investigate the effects of the individual hormones.

\section{Behavioral changes across the Estrous CYCLE}

Some of the major behavioral variations across the estrous cycle are summarized in Table 2.

\section{PROESTRUS}

Mora and colaborators (1996) described lower anxiety level in P females submitted to plus-maze testing compared with other stages of the cycle. The plus-maze apparatus consist generally of two open arms, two closed arms and a central platform, arranged such that the two arms of each type are opposite to each other, all elevated about $70 \mathrm{~cm}$ from the floor. Anxiety is reflected in the aversion to heights; time spent in open arms is increased by anxiolytics and reduced by anxiogenic treatments (see Mora et al., 1996). P exhibits the highest peak levels of the anxiolytic P4 
(and ALLO), the anti-stress PRL, and the controversial E2. This anxiolytic effect has been correlated with increased circulating levels of endogenous ALLO on P, and can be prevented by blockage of ALLO synthesis (see Smith at al., 2007). However, low levels of anxiety have also been described during $\mathrm{P}$ morning, when plasma P4 is at its lowest level, prior to the preovulatory surge (see Lovick, 2006). The falling P4 levels, rather than the absolute concentration of the steroid, can lead to significant changes in the excitability of GABA-containing circuits (see Lovick, 2006). PRL is another putative hormone that may cause the lower scores of anxiety observed at $\mathrm{P}$, since a peak of PRL is observed at this stage (Furudate et al., 1989) and the anti-stress properties of PRL have been well documented (see Fracchia et al., 1992; Torner et al., 2001; Torner, Toschi, Neva, Clapp, \& Neumann, 2002; Donner \& Handa, 2009).

Controversially, Figueiredo, Dolgas \& Herman (2002) found increased HPA activity in $\mathrm{P}$ females. These authors report a low activity of the cingulate cortex and hippocampus, that may result in a decrease in HPA inhibitory outflow. In the hippocampus, dendritic spine density increases on the day of $\mathrm{P}$, and this effect has been attributed to E2, presumably by enhancing neuronal sensitivity to glutamatergic imputs, and by reducing GABAergic influences. These E2 effects on hippocampal neurons can be reversed by $\mathrm{P} 4$ and its metabolites (Figueiredo el al., 2002).

Object recognition has also been described to be enhanced in P. Progestins such as $\mathrm{P} 4$ have been proposed to be responsible of this improved performance, since the rats in natural states associated with higher endogenous progestins ( $\mathrm{P}$, pregnancy and multiparity) outperformed the rats with low progestin states (D, non-pregnancy, nulliparity) on object placement and recognition tasks (Paris \& Frye, 2008). The object recognition task is a working memory task, and a variety of versions of this test have been published. In brief, animals are trained to recognize objects and / or placements of objects, and during a testing trial one of the objects is replaced or placed in another location. An increase in the time spent exploring the novel object is considered an index of enhanced cognitive performance in this task (see Paris \& Frye, 2008).

A measure for sensorimotor gating deficits in humans and animals is the disruption of prepulse inhibition (PPI) of the acoustic startle response (ASR). PPI is the reduction of the ASR that is normally observed when the startling pulse is preceded by a weak prepulse. Eye blink and eye movement artifacts are the most common ASR recorded. PPI is significantly reduced in P. Because DA and 5-HT regulate PPI, it has been proposed that E2 may interact with these monoamine systems (Koch, 1998).

The DA system is affected during P. A prolonged DA transport in nucleus accumbens has been described (Thompson \& Moss, 1997). DA release in the striatum, particularly in nucleus accumbens, has been postulated to mediate the reinforcing properties of food, drugs of abuse, and sexual experience. Alternatively, it has been suggested that an increase in extracellular DA in nucleus accumbens or striatum may be associated with stimuli predicting reinforcement (see Becker, Charles, Rudick, William, \& Jenkins, 2001).

\section{ESTRUS}

Mora and colaborators (1996) described a slight decrease in the behavioral stress response in $\mathrm{E}$ female rats exposed to elevated plus maze under low light condition. Lower ACTH and corticosterone circulating levels could be involved in this attenuation (Atkinson \& Waddell, 1997; Haim, Shakhar, Rossene, Taylor, \& Ben-Eliyahu, 2003). Similarly to P stage, high levels of PRL could also contribute to attenuate the stress response when compared to D stages (Furudate et al., 1989). A novel peptide, the Prolactin Releasing Peptide (PrRP), which is sensitive to E2 fluctuation, has been linked to the lower activity of the HPA axis. Stress-induced activation of PrRP neurons is significantly decreased in E compared with P, D1 and D2, suggesting that E2 suppresses the activation of PrRP neurons (Adachi et al., 2005). PrRP stimulates 
the CRH-mediated ACTH secretion, and modulates, cooperatively with noradrenaline, the HPA axis (Maruyama et al., 2001). In rats P4 also falls during $\mathrm{P}$ following the preovulatory surge, resulting in low values of $\mathrm{P} 4$ in E. However, the dynamics of this event are not sufficient enough to trigger the changes in GABAergic function observed in the late $\mathrm{D}$, as described later on (see Lovick, 2006).

An enhancement of DA release in the striatum and of DA-mediated behaviours was reported (Becker, 1999); this would be mediated by $\mathrm{E} 2$ in the E. This finding, however, is not in agreement with other authors. In the nucleus accumbens, $\mathrm{K}+$ stimulated DA release peaks during D1 and decreases during D2 and E (Thompson \& Moss, 1997). Laconi, Reggiani, Penissi, Yunes, \& Cabrera (2007) found a decrease in the striatal concentrations of both DA and DOPAC after i.c.v. injection of ALLO in $\mathrm{E}$, but it is just in this stage when P4 and ALLO exhibit the lowest circulating levels. On the other hand, on hippocampal neurons, E2 causes an increase in dendritic spine density with a reduction in GABAergic inhibition, resulting in an enhanced excitatory tone (Murphy, Cole, Greenberger, \& Segal, 1998).

\section{DiESTRUS}

The late luteal phase (late diestrus in rats, D2) correlates with the premenstrual phase in women, commonly associated with psychological disturbances, including mood disorders and increased aggression (see Lovick \& Devall, 2009). Consistently, increased levels of anxiety and aggression have been detected in rats during $\mathrm{D}$, when plasma progesterone is rising (see Lovick, 2006). However, these findings were not replicated in mice, since increased levels of anxiety have been described during $E$ rather than D (see Lovick, 2006).

The stress-induced freezing behaviour has been reported to be under the control of the periaqueductal gray (PAG) (Brandão, Zanoveli, Ruiz-Martinez, Oliveira, \& Landeira- Fernandez, 2008), hipoccampus (Fisher, Radulovic, M., Schrick, Sananbenesi, GodovacZimmermann, \& Radulovic, J., 2007), amyg- dala (Guarraci, Frohardt, \& Kapp, 1999), and striatum (Becker, 1999). Freezing might be defined as the complete absence of body movement in response to fear stimuli or threatening contexts (see Fisher et al., 2007; Brandão et al., 2008). Brandão and collaborators (2008) proposed a model of serotonergic modulation of freezing behavior through on- and off-cells of the defense reaction in the PAG. The hippocampus may contribute to the extinction of fear-motivated behaviors; recently, molecular key mediators (hippocampal extracellular signal-regulated kinase [Erk] and mitogen activated and extracellular signal-regulated kinase [Mek] signaling) have been involved in contextual fear extinction, measured as a decrease in freezing behavior (Fisher et al., 2007). DA transmission within the amygdala would contribute as well to the fear conditioning measured by freezing in response to acoustic and background contextual stimuli, perhaps through the mesoamygdaloid dopaminergic system (Guarraci et al., 1999). All the brain structures mentioned above are suitable to be influenced by gonadal hormones. The pattern of gonadal steroid hormones in the rat striatum is similar to the pattern in the circulation during the cycle and affects the morphology and plasticity of the neurons (Morisette, García-Segura, Béianger, \& Di Paolo, 1992) and the number of DA uptake sites (Morisette \& Di Paolo, 1993). In nucleus accumbens, K+ stimulated DA release peaks during D1 and decreases during D2 and E, as seen using in vivo electrochemical techniques (Thompson \& Moss, 1997).

A novel object placed in the center of a plexiglass cage with automatically motor scoring was used to assess exploratory and motor behavior. We have measured the disruption of exploratory behavior in intact female rats exposed to a sudden sound stimulus, lasting one minute, and the posterior restoration of this behavior to baseline scores. Freezing and post-stress inhibition of rearing and exploration were potentiated in the D stage. Since striatum DA is involved in motor activity, it may contribute to the increase of this inhibitory response. 
The midbrain PAG plays a major role in mediating panic responses (see Smith et al., 2007). The GABAergic tone on the output neurons in the PAG is reduced during late $\mathrm{D}$ (D2), lowering the threshold for activation of the panic circuitry (see Lovick, 2006).

\section{ESTROUS CYCLE INDUCED CHANGES ON SOME OF THE MAJOR NEUROTRASMISSION SYSTEMS}

\section{THE GABA SYSTEM}

The GABA system is the main inhibitory system in the brain. Activation of GABA pathways inhibits or attenuates neural transmission in the other systems. Benzodiazepin-induced anxiolysis is mediated by $\mathrm{GABA}_{\mathrm{A}}$ receptors. GABA receptors are composed of several subunits, and the different subunit combinations generate several subtypes of receptors that mediate different responses and intracellular signaling pathways. $\mathrm{GABA}_{\mathrm{A}}$ receptors are the main inhibitory mediators in the central nervous system and are essential for circuit activity and gating of relevant sensory signals (see Smith et al., 2007). The function of these receptors is determined by their subtype, which is modulated mainly by neurosteroids through an allosteric binding site (see Smith et al., 2007). Estrous-cycle-dependent increases in $\delta$-GABA ${ }_{\mathrm{A}}$ receptors have been described; this subtype that underlies a tonic inhibitory current, is the most sensitive target of P4 and ALLO (see Smith et al., 2007).

Lovick, Griffiths, Dunn, and Martin (2005) found an increased expression of some $\mathrm{GABA}_{\mathrm{A}}$ receptor subunits in the interneurones of PAG as a consequence of the falling of gonadal steroid levels. This could render the panic circuitry abnormally excitable by disinhibiting the ongoing GABAergic inhibition. It is known that the subunit composition of a receptor is determinant of its function. Fluctuation of $\mathrm{P} 4$ was reported to induce changes in $\mathrm{GABA}_{\mathrm{A}}$ receptor subunit expression in cerebral cortex, hippocampus, amygdala, and PAG (see Lovick, 2006). In females GABA tone in the PAG is reduced during D2. This occurs also in E, though this is unlikely related to plasticity of the GABA $\alpha 4 \beta 1 \delta$ receptor expression (see Lovick \& Devall, 2009). During D2, E2 levels are low and stable, suggesting that changes in P4 rather than E2 levels are responsible for the changes in PAG function during D2 (see Lovick \& Devall, 2009). On late D (D2), the $\alpha 4, \beta 1$ and $\delta$ subunit expression of the $\mathrm{GABA}_{\mathrm{A}}$ receptors is increased in PAG interneurons, which is consistant with ALLO withdrawal (see Smith et al., 2007). Injection of bicuculline as well as the panicogenic cholecystokinin ligand, pentagastrin, increased PAG neuronal activity to a greater extent in $\mathrm{E}$ and D2. Activation of these PAG output neurons has been shown to elicit a panic reaction both in humans and rodents (see Smith et al., 2007).

Increased expression in $\delta$ subunit has been correlated with increased amplitude of the tonic current from the dentate gyrus granule cells in the D1 mice (see Smith et al., 2007). Increased expression of $\alpha 4$ subunit in hippocampus, amygdala and PAG, of $\delta$ subunit in hippocampus, of $\beta 1$ and $\delta$ subunits in PAG, and of $\alpha 1$ and $\alpha 4$ subunits in cerebral cortex have been reported during withdrawal from P4. During the D2, when levels of P4 are falling, $\alpha 4, \beta 1$ and $\delta$ subunit expression is increased (see Lovick, 2006).

Decreases in systemic P4 in rats are associated with an increase in anxiety or aggression (see Lovick, 2006). After pharmacological withdrawal from P4 the modulatory effect of benzodiazepines is reduced (see Lovick, 2006). Physiological fluctuations in the concentrations of $\mathrm{P} 4$, as those occurring at the D1 stage, play a major role in determining the temporal pattern of expression of certain subunits of the GABA ${ }_{A}$ receptor (see Maguire \& Mody, 2007; Lovick \& Devall, 2009). Under this influence a particular configuration of $\mathrm{GABA}_{\mathrm{A}}$ receptors would be expected to lead to a reduction of their activity level, thus disinhibiting the output neurons within the periaqueductal gray (PAG) by reducing the level of ongoing GABAergic tone (see Lovick $\&$ Devall, 2009). PAG contains neural circuitry involved in the generation of panic-like anxiety 
(see Lovick, 2006). A reduction in the level of GABAergic inhibition leads to an overall excitability of the PAG output neurons (see Lovick, 2006), which become intrinsically more excitable, by lowering their activation threshold (see Lovick \& Devall, 2009). This subtype of $\mathrm{GABA}_{\mathrm{A}}$ receptor is also insensitive to benzodiazepine modulation, suggesting an intrinsic state of hyperexcitability (see Smith et al., 2007).

The increase in anxiety due to $\mathrm{P} 4$ withdrawal was enhanced when E2 was coadministered (see Smith et al., 2007). E2 causes a twofold rise in dendritic spine density in hippocampal neurons. Estrogen receptors have been localized in spiny inhibitory hippocampal interneurons. E2 causes a reduction in GABAergic inhibition, leading to an increase in the excitatory tone (Murphy et al., 1998). It also acts indirectly on pyramidal cells by causing a transient lowering of GABA synthesis in the interneurons (Murphy et al., 1998). All these findings suggest an excitatory role for E2 through inhibition of the GABA system.

\section{THE SEROTONIN SYSTEM}

The serotonin system, deeply involved in neurochemical processes such as stress, anxiety and depression, also exhibits variations along the estrous cycle, though many of these may be linked to the estrous-cycle dependant GABA-receptor changes. Serotonin (5-HT)producing neurons project to almost every area of the forebrain and regulate higher order neural processes. The ability of estrogens and progestins to regulate the function of 5-HT neural systems at different levels provides a cellular mechanism whereby ovarian hormones can impact on cognition, mood or arousal, hormone secretion, pain, and other neural circuits (Bethea, Lu, Gundlah, \& Streicher, 2002). During P and E, baseline 5HT levels are elevated in the Dorsal raphe nucleus (DRN) (Felton \& Auerbach, 2004). Brandão and colaborators (2008) proposed a model of serotonergic modulation of freezing behavior through on- and off-cells of the defense reaction in the PAG.
It is known that 5-HT stimulates the secretion of corticotrophin releasing hormone (CRH) and ACTH both at the hypothalamic, pituitary portal and pituitary gland level, and possibly also at the adrenal gland (Jørgensen, 2007). CRH is involved in the 5-HT-induced release of ACTH. Stimulation of the $5-\mathrm{HT}_{\mathrm{A}}$, $5-\mathrm{HT} 1_{\mathrm{B}}, 5-\mathrm{HT} 2_{\mathrm{A}}$ and $5-\mathrm{HT} 2_{\mathrm{C}}$ receptors elicits an increase of CRH mRNA in the paraventricular nucleus of the hypothalamus and of proopiomelanocortin in the anterior pituitary lobe (Jørgensen, 2007). Extracellular 5-HT in the mediobasal hypothalamus varies with the stage of the estrous cycle and also with the light / dark cycle, with highest concentrations in $\mathrm{P}$ females during the light period and the lowest during the dark period. Maswood, Truitt, Hotema, Caldarola-Pastuszka, and Uphouse (1999) reported that D females had the highest 5-HT levels during the dark, while males and E female's 5-HT levels were poorly affected by the light/dark cycle. Estrogens exert a biphasic effect on the 5-HT receptor density in the brain; it induces an initial acute reduction throughout the brain, followed by a selective increase in those brain regions known to contain estrogen receptors: i.e. hypothalamus, preoptic area, and amygdala (Biegon \& McEwen, 1982).

Hiroi, McDevitt, and Neumaier (2006) postulated that ovarian steroids may modulate anxiety behavior by regulating 5-HT neurons in the midbrain raphe nucleus. Estrogen selectively increases expression of tryptophan hydroxylase-2 (TPH2), the key regulatory enzyme in 5-HT synthesis, in the dorsal and median raphe nuclei. The increases in TPH2 mRNA in the caudal dorsal raphe nucleus (DRN) was associated with lower anxiety-like behavior in an open field test, whereas TPH2 mRNA expression in the rostral dorsomedial raphe nuleus was associated with increased anxiety-like behavior. In an open field test arena, center time is considered a reliable index of anxiety, responds to anxiolytic agents, and is sensitive to stress-induced anxiety states; there are also a number of studies examining corner time in the open field (see Hiroi \& Neumaier, 2009). Expression of THP2 mRNA within 5HT neurons of the rat DRN is up regulated by 
the Estrogen receptor $\beta$, and their agonists have been shown to attenuate anxiety- and despairlike behaviors in rodent models (Donner \& Handa, 2009). 5-HT1 $1_{B}$ mRNA in midventromedial subregion of the DNR has been associated with higher anxiety-like behavior and was inversely correlated with TPH2 mRNA levels (Hiroi \& Neumaier, 2009). Estrogens selectively decreased $5-\mathrm{HT} 1_{\mathrm{B}}$ mRNA in this subregion, with a consequent downregulation of the inhibitory $5-\mathrm{HT} 1_{B}$ autoreceptors and increase of TPH2 synthesis in a coordinated fashion, thereby increasing the capacity for 5-HT synthesis and release (Hiroi \& Neumaier, 2009).

The main regulatory influence on 5-HT release in the DRN is mediated by $\mathrm{GABA}_{\mathrm{A}}$ receptors (Tao \& Auberbach, 2000). The $\mathrm{GABA}_{\mathrm{A}}$ antagonists produce a greater increase of 5-HT in the DRN during P compared to E, and a negligible increases in 5-HT in ovariectomized rats, providing evidence of a decreased 5-HT efflux and GABA tone in the rat DRN associated with low circulating E2 and P4 hormones (Felton \& Auerbach, 2004).

\section{THE DOPAMINE SYSTEM}

Gender differences have been described for dopamine (DA) function in the striatum and nucleus accumbens, due to E2 and P4 modulation (Becker, 1999). DA release and reuptake fluctuate with changes in circulating steroid levels (Thompson \& Moss, 1997). E2 enhances DA release and DA-mediated behaviors, such as increased general activity, food seeking behavior and sexual motivation (Becker, 1999). E2 induces a rapid change in neuronal excitability by acting on intrinsic striatal GABAergic neurons and on DA terminals (Becker, 1999). ALLO modulates striatal dopaminergic activity (Laconi et al., 2007). Cyclic fluctuation of ovarian steroids may modulate DA activity presynaptically through an alteration of both release and reuptake in the mesolimbic DA system (Thompson \& Moss, 1997).

Thompson and Moss (1997) proposed a protective effect of E2 on DA activity. It has been suggested that hormonal modulation in the striatum may have evolved to facilitate reproductive success in female rats by enhancing pacing behavior (Becker, 1999). DA transmission within the amygdala contributes to the acquisition and expression of Pavlovian fear conditioning measured by freezing to acoustic and background contextual stimuli, maybe through the mesoamygdaloid dopaminergic system (Guarraci et al., 1999). Sex differences or hormone malleability have also been demonstrated for the prefrontal cortical DA axon density and growth, as well as for DA levels and turnover (Kritzer \& Creutz, 2008).

Brain stimulation reward depends on the functioning of the mesolimbic DA system. E in intact rats, and E2 replacement in ovariectomized rats increase the rewarding value of stimulation, thus indicating a modulatory effect on the DA system (Bless, McGinnis, Mitchell, A., Hartwell, \& Mitchell, J., 1997).

\section{Prolactin-RELEASING PEPTIDE}

Prolactin-releasing peptide (PrRP) is produced in hypothalamic, thalamic and amygdaloid nuclei, the pituitary gland and the bed nucleus of the stria terminalis (Maruyama, Matsumoto, Fujiwara, Kitada, Himuna, Onda, Fujino, \& Inoue, 1999). It has been proposed as a mediator of stress responses (Maruyama et al., 2001; Adachi et al., 2005). Though gender differences have been described, the distribution of PrRP does not change during the estrous cycle (Tóth et al., 2008). In the brain stem it colocalizes with norepinephrine in neurons of the A1/A2 noradrenergic nuclei (Adachi et al., 2005; Tóth et al., 2008). In the brain stem, but not in the hypothalamus, the basal PrRP expression in female rats is higher than in males (Tóth et al., 2008). Estrogen $\alpha-$ receptors were found in the PrRP neurons of the A1 and A2 cell groups, but not in the hypothalamus (Tóth et al., 2008). Estrogen modulates the stress response of PrRP neurons through binding to estrogen $\alpha$-receptors, suppressing the activation of PrRP neurons (Adachi et al., 2005). 


\section{CONCLUSION}

We have reviewed only general variations on some systems of neurotransmitters. Steroid and PRL receptors are spread widely in mammals, including the nervous system, and cyclic fluctuation in the sex hormones also influences a variety of physiological events other than behavior. About thirty non steroid susbstances are produced in the ovary in a cyclic manner, some with recognized behavioural properties, such us oxitocin, reninangiotensin and vasopresin, but none of these have been included in the present work. An extensive review would exceed a single article for publication. We have chosen some brain systems whose cyclic variations have been well documented.

We have also focused on the stress response. Sexual dimorphism has been described for the HPA-axis activity. Gonadal steroids have been proposed to play a role in HPA-axis regulation, since neuroendocrine and behavioural responses to acute stress are modulated by sex and the stage of the estrous cycle (Figueiredo et al., 2002). Studies on HPA activity in female rats suggest a facilitatory role for E2 while the effects of P4 appear to be inhibitory (Carey \& de Kloet, 1994). Decreases in systemic P4 in rats are associated with increased anxiety or aggression (see Lovick, 2006). After withdrawal from P4 the modulatory effect of benzodiazepines is reduced (see Lovick, 2006). Enhanced HPA activity under both basal and stressful conditions were described for late Proestrus, at the time of elevated circulating concentrations of both E2 and P4 (Carey \& de Kloet, 1994). Stress may also alter both female and male reproduction. In this regard, it has been pointed out divergent effects of corticosteroids and ACTH on stress responses: chronic stress may inhibit cyclicity and fertility (Rodríguez Echandía, González, Cabrera, \& Fracchia, 1988), as well as sexual maturation and pregnancy, while some acute stresses exert a facilitatory effect, enhancing fertility, ovulation and sexual behaviour (see Brann \& Mahesh, 1991).

We hope this work may contribute to a better understanding of the female cyclicity in pharmacological and behavioural responses. This may help to improve diagnostic features and therapeutic treatments.

TABLE 1

Behavioral effects of Estradiol (E2), Progesterone (P4) and Prolactine (PRL)

\begin{tabular}{|l|l|}
\hline E2 & $\begin{array}{l}\text { Antidepressant properties (Walf \& Frye, 2005) } \\
\text { Enhanced locomotion (open field) (Ogawa et al., 2003) } \\
\text { Reduced inmobility (forced swim test) (Walf \& Frye, 2005) } \\
\text { Fear conditioning: controversial (Toufexis et al., 2007) }\end{array}$ \\
\hline P4 & Anxiolytic benzodiazepine-like properties (Mora et al., 1996; Laconi et al., 2001) \\
\hline PRL & Anti-stress properties (Furudate et al., 1989; Fracchia et al., 1992; Torner et al., 2001) \\
\hline
\end{tabular}




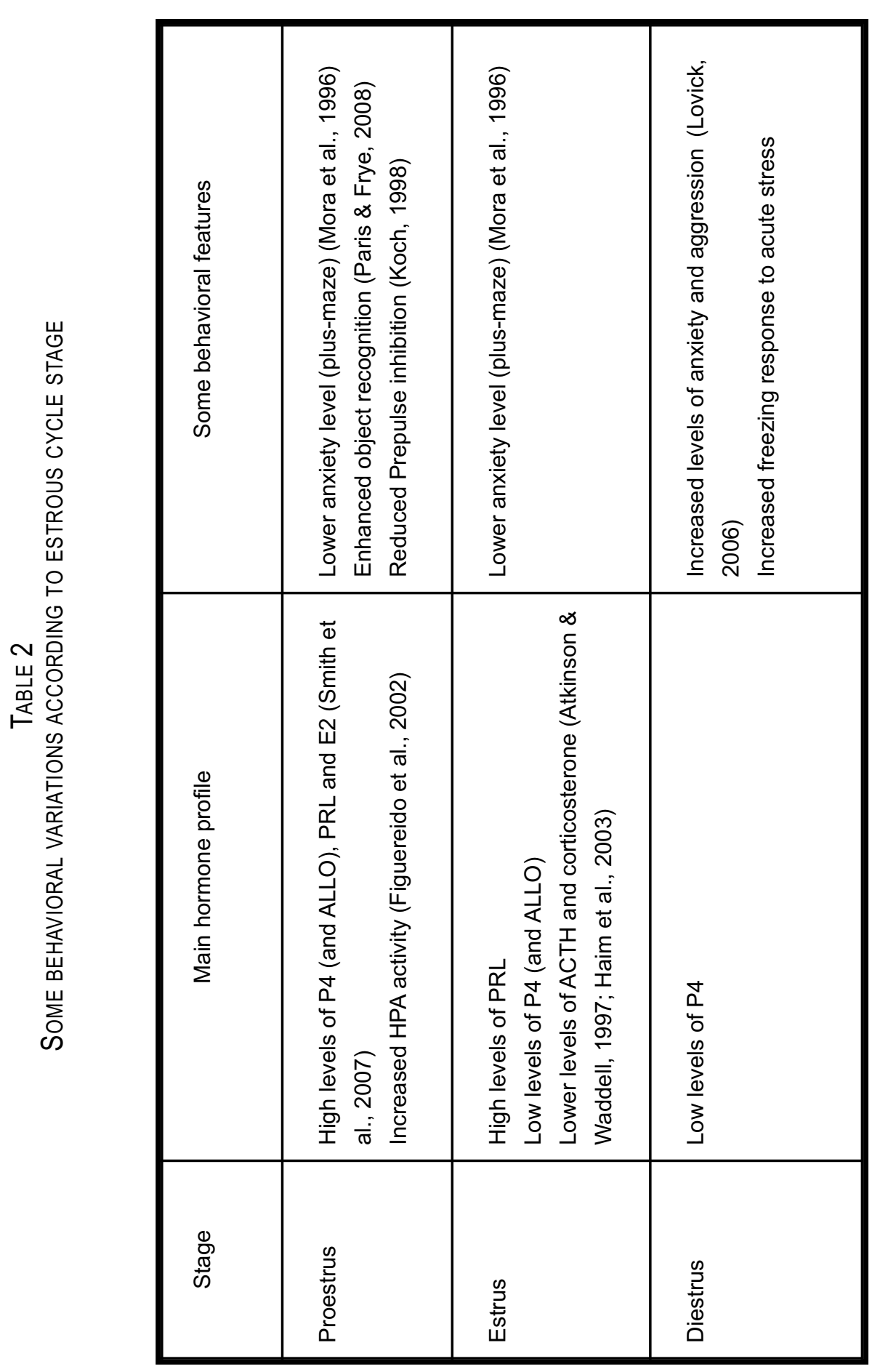




\section{REFERENCES}

Adachi, S., Mochiduki, A., Nemoto, H., Sun, B., Fujiwara, K., Matsumoto, H., \& Inoue, K. (2005). Estrogen suppresses the stress response of prolactin-releasing peptide-producing cells. Neuroscience Letters, 380(3), 311-315. doi: 10.1016/j.neulet.2005.01.064.

Atkinson, H.C. \& Waddell, B.J. (1997). Circadian variation in basal plasma corticosterone and adrenocorticotropin in the rat: Sexual dimorphism and changes across the estrous cycle. Endocrinology, 138(9), 3842-3848. doi: 10.12 10/en.138.9.3842.

Becker, J.B. (1999). Gender differences in dopaminergic function in striatum and nucleus accumbens. Pharmacology Biochemistry and Behavior, 64(4), 803-812. doi:10.1016/S009 13057(99)00168-9.

Becker, J.B., Charles, N., Rudick, I., William, J., \& Jenkins, I. (2001). The role of dopamine in the nucleus accumbens and striatum during sexual behavior in the female rat. The Journal of Neuroscience, 21(9), 3236-3241. Retrieved March 26 2012, from http://www.jneurosci. org/content $/ 21 / 9 / 3236$.full

Ben-Jonathan, N., LaPensee, C.R., \& LaPensee, E.W. (2008). What can we learn from rodents about prolactin in humans? Endocrine Reviews, 29(1), 1-41. doi: 10.1210/er.2007-0017

Bethea, C.L., Lu, N.Z., Gundlah, C., \& Streicher, J.M. (2002). Diverse actions of ovarian steroids in the serotonin neural system. Frontiers Neuroendocrinology, 23(1), 41-100. doi: 10.1006/ frne.2001.0225.

Biegon, A. \& McEwen, B.S. (1982). Modulation by estradiol of serotonin receptors in brain. The Journal of Neuroscience, 2(2), 199-205. Retrieved March 26 2012, from http://www.jne urosci.org/content/2/2/199.full.pdf

Bless, E.P., McGinnis, K.A., Mitchell, A.L., Hartwell, A., \& Mithchell, J.B. (1997). The effects of gonadal steroids on brain stimulation reward in female rats. Behavioural Brain
Research, 82(2), 235-244. doi: 10.1016/ j.bbr. 2011.03.031.

Brandão, M.L., Zanoveli, J.M., Ruiz-Martinez, R.C., Oliveira, L.C., \& Landeira-Fernandez, J. (2008). Different patterns of freezing behavior organized in the periaqueductal gray of rats: Association with different types of anxiety. Behavioural Brain Research, 188(1), 1-13. doi: 10.1016/j.bbr.2007.10.018.

Brann, D.W. \& Mahesh, V.B. (1991). Role of corticosteroids in female reproduction. FASEB Journal, 5, 2691-2698. Retrieved March 26 2012, from http://www.fasebj.org/content/5/ 12/2691.full.pdf + html.

Carey, M.P. \& de Kloet, E.R. (1994). Interaction of progesterone with the hippocampal mineralocorticoid receptor. Annals of the New York Academy of Sciences, 746, 434-437. doi: 10.1111/ j.1749-6632.1994.tb39278.x.

Donner, N. \& Handa, R.J. (2009). Estrogen receptor beta regulates the expression of tryptophan-hydroxylase 2 mRNA within serotonergic neurons of the rat dorsal raphe nuclei. Neuroscience, 163(2), 705-718. doi: 10.1016/j. neuroscience.2009.06.046.

Felton, T.M. \& Auerbach, S.B. (2004). Changes in gamma-aminobutyric acid tone and extracellular serotonin in the dorsal raphe nucleus over the rat estrous cycle. Neuroendocrinology, 80 (3), 152-157. doi: 10.1159/000082356.

Figueiredo, H.F., Dolgas, C.M. \& Herman, J.P. (2002). Stress activation of cortex and hippocampus is modulated by sex and stage of estrus. Endocrinology, 143(7), 2534-2540. doi: 10.1210/en.143.7.2534.

Fischer, A., Radulovic, M., Schrick, C., Sananbenesi, F., Godovac-Zimmermann, J., \& Radulovic, J. (2007). Hippocampal Mek/Erk signaling mediates extinction of contextual freezing behavior. Neurobiology of Learning and Memory, 87(1), 149-158. doi: 10.1016/j.nlm. 2006.08.003.

Fracchia, L.N., González Jatuff, A.S., \& Alvarez, E.O. (1992). The effect of chronic unpre- 
dictable stress on locomotor and exploratory activity in male rats with different endogenous prolactin levels. Journal of Neural Transmission [GenSect], 89, 179-192. Retrieved March 26 2012, from http://www.ncbi.nlm. nih.gov/pubmed/1389002.

Furudate, S., Ashihara, H., \& Nakano, T. (1989). Prolactin secretion and its response to stress during the estrous cycle of the rats. Jikken Dobutsu, 38(4), 313-318. Retrieved March 26 2012, from http://www.ncbi.nlm.nih.gov/ sites/ entrez? $\mathrm{Db}=$ pubmed $\& \mathrm{Cmd}=$ Retrieve\&list_uids $=2806389 \& \mathrm{dopt}=$ abstractplus.

Guarraci, F.A., Frohardt, R.J., \& Kapp, B.S. (1999). Amygdaloid D1 dopamine receptor involvement in Pavlovian fear conditioning. Brain Research, 827(1-2), 28-40. doi: 10.10 16/j.bbr.2011.03.031.

González Jatuff, A.S., Berástegui, M., Rodríguez, C.I., \& Rodríguez Echandía, E.L. (1999). Permanent and transient effects of repeated preweaning stress on social and sexual behaviors of rats. Stress, 3(2), 97-106. Retrieved March 26 2012, from http://www.ncbi.nlm. nih.gov/pubmed/10938572.

Haim, S., Shakhar, G., Rossene, E., Taylor, A.N., $\&$ Ben-Eliyahu, S. (2003). Serum levels of sex hormones and corticosterone throughout 4- and 5-day estrous cycles in Fischer 344 rats and their simulation in ovariectomized females. Journal of Endocrinological Investigation, 26(10), 1013-1022. Retrieved March 26 2012, from http://www.ncbi.nlm.nih.gov/pubmed/14 759076.

Hiroi, R., McDevitt, R.A., \& Neumaier, J.F. (2006). Estrogen selectively increases tryptophan hydroxylase-2 mRNA expression in distinct subregions of rat midbrain raphe nucleus: Association between gene expression and anxiety behavior in the open field. Biological Psychiatry, 60(3), 288-295. doi:10.1016/j.bio psych.2005.10.019.

Hiroi, R. \& Neumaier, J.F. (2009). Estrogen decreases 5-HT1B autoreceptor mRNA in selec- tive subregion of rat dorsal raphe nucleus: inverse association between gene expression and anxiety behavior in the open field. Neuroscience, 158(2), 456-464. doi: 10.1016/j.bbr. 2011.03.031.

Jørgensen, H.S. (2007). Studies on the neuroendocrine role of serotonin. Danish Medical Bulletin, 54(4), 266-288. Retrieved March 26 2012, from http://www.dadlnet.dk/dmb/DM B_2007/0407/04-07-disputatser/ DM B3960. pdf.

Kritzer, M.F. \& Creutz, L.M. (2008). Region and sex differences in constituent dopamine neurons and immunoreactivity for intracellular estrogen and androgen receptors in mesocortical projections in rats. The Journal of Neuroscience, 28(38), 9525-9535. doi:10.1523/JNEU R OSCI.2637-08.2008.

Koch, M. (1998). Sensorimotor changes across the estrous cycle in female rats. Physiology and Behavior, 64(5), 625-628. doi: 10. 1016/S00319384(98)00098-5.

Laconi, M.R., Casteller, G., Gargiulo, P.A., Bregonzio, C., \& Cabrera, J.R. (2001).The ansiolytic effect of allopregnanolone is associated with gonadal hormonal status in female rats. European Journal of Pharmacology, 417, 111116. doi:10.1016/j.bbr.2011.03.031.

Laconi, M.R., Reggiani, P.C., Penissi, A., Yunes, R., \& Cabrera, R.J. (2007). Allopregnanolone modulates striatal dopamingergic activity of rats under different gonadal hormones conditions. Neurological Research, 29(6), 622-627. doi:10.1179/016164107X166281.

Lancel, M., Faulhaber, J., Holsboer, F., \& Rupprecht, R. (1999). The GABA(A) receptor antagonist picrotoxin attenuates most sleep changes induced by progesterone. Psychopharmacology, 141(2), 213-219. doi: 10.1007/ s002130050827.

Lovick, T.A. (2006). Plasticity of GABA ${ }_{A}$ receptor subunit expression during the oestrouscycle of the rat: implications for premenstrual syndrome in women. Experimental Physiol- 
ogy, 91(4), 655-660. doi: 10.1113/expphysiol. 2005.032342.

Lovick, T.A. \& Devall, A.J. (2009). Progesterone withdrawal-evoked plasticity of neural function in the female periaqueductal grey matter. Neural Plasticity, 2009. doi: 10.1155/2009/ 730902.

Lovick, T.A., Griffiths, J.L., Dunn, S.M., \& Martin, I.L. (2005). Changes in GABA(A) receptor subunit expression in the midbrain during the oestrus cycle in Wistar rats. Neuroscience, 131(2), 397-405. doi: 10.1016/j.bbr. 2011.03.03.

Maguire, J. \& Mody, I. (2007). Neurosteroid synthesis-mediated regulation of $\mathrm{GABA}_{\mathrm{A}}$ receptors: Relevance to the ovarian cycle and stress. Journal of Neuroscience, 27(9), 2155-2162. doi: 10.1523/JNEUROSCI.4945-06. 2007.

Maruyama, M., Matsumoto, H., Fujiwara, K., Kitada, C., Himuna, S., Onda, H., Fujino, M., \& Inoue, K. (1999). Immunocytochemical localization of prolactin-releasing peptide in the rat brain. Endocrinology, 140(5), 2326-2333. doi: 10.1210/en.140.5.2326.

Maruyama, M., Matsumoto, H., Fujiwara, K., Noguchi, J., Kitada, C., Fujino, M., \& Inoue, K. (2001). Prolactin-releasing peptide as a novel stress mediator in the central nervous system. Endocrinology, 142(5), 2032-2038. doi: 10.1210/en.142.5.2032.

Maswood, S., Truitt, W., Hotema, M., CaldarolaPastuszka, M., \& Uphouse, L. (1999). Estrous cycle modulation of extracellular serotonin in mediobasal hypothalamus: Role of the serotonin transporter and terminal autoreceptors. Brain Research, 12(1-2), 146-154. doi: 10.101 6/S0006-8993(99)01439-0.

Méndez, I., Cariño, C., \& Díaz, L. (2005). Prolactin in the immunological system: Synthesis and biological effects. Revista de Investigación Clínica, 57(3), 447-456. Retrieved March 26 2012, from http://new.medigraphic.com/cgibin/resumenI.cgi?IDREVISTA $=77 \&$ IDART ICULO $=6390 \&$ IDPUBLICACION $=754$.
Mora, S., Dussaubat, N., \& Díaz-Véliz, G. (1996). Effects of the estrous cycle and ovarian hormones on behavioural indices of anxiety in female rats. Psychoneuroendocrinology, 21, 609620. doi:10.1016/S0306-4530(96)00015-7.

Morisette, M., García-Segura, L.M., Béianger, A., \& Di Paolo, T. (1992). Changes of rat striatal neuronal membrane morphology and steroid content during the estrous cycle. Neuroscience, 49(4), 893-902. doi: 10.1016/ 0306-4522(92) 90365-9.

Morisette, M. \& Di Paolo, T. (1993). Sex and estrous cycle variations of rat striatal dopamine uptake sites. Neuroendocrinology, 58(1), 1622. Retrieved April 2 2012, from http://www. ncbi.nlm.nih.gov/pubmed/8264850.

Murphy, D.D., Cole, N.B., Greenberger, V., \& Segal, M. (1998). Estradiol increases dendritic spine density by reducing GABA neurotransmission in hippocampal neurons. Journal of Neuroscience, 18(7), 2550-2559. Retrieved April 2 2012, from en http://www. jneurosci. org/content/18/7/2550.full.

Ogawa, S., Chan, J., Gustafsson, J., Korach, K.S., \& Pfaff, D.W. (2003). Estrogen increases locomotor activity in mice through estrogen receptor $\alpha$ : Specificity for the type of activity. Endocrinology, 144, 230-239. doi: 10.1210/ en.2002-220519.

Paris, J.J. \& Frye, C.A. (2008). Estrous cycle, pregnancy, and parity enhance performance of rats in object recognition or objet placement tasks. Reproduction, 136(1), 105-115. doi: 10. 1530/REP-07-0512.

Poletini, M.O., Szawka, R.E., Franci, C.R., \& Anselmo-Franci, J.A. (2006). Ovarian steroids but not the locus coeruleus regulate stress-induced prolactin secretion in female rats. Journal of Neuroendocrinology, 18(12), 938948. doi: 10.1111/j.1365-2826.2006.01491.x.

Rodríguez Echandía, E.L., González, A.S., Cabrera, R., \& Fracchia, L.N. (1988). A further analysis of behavioral and endocrine effects of unpredictable chronic stress. Physiology and 
Behaviour, 43(6), 789-795. doi: 10.1016/0031 9384(88)90378-2

Semprini, S., Friedrichsen, S., Harper, C.V., Mc Neilly, J.R., Adamson, A.D., Spiller, D.G., Kotelevtseva, N., Brooker, G., Brownstein, D.G., McNeilly, A.S.,White, M.R., Davis, J.R., \& Mullins, J.J. (2009). Real-time visualisation of human prolactin alternate promoter usage in vivo using a Double-Transgenic Rat Model. Molecular Endocrinology, 23(4), 529-538. doi: 10.1210/me.2008-0399.

Smith, S.S., Shen, H., Gong, Q.H., \& Zhou, X. (2007). Neurosteroid regulation of $\mathrm{GABA}_{\mathrm{A}}$ receptors. Focus on the $\alpha 4$ and $\delta$ subunits. Pharmacology and Therapeutics, 116(1), 5876. doi: 10.1016/j.pharmthera.2007.03.008.

Tao, R. \& Auerbach, S.B. (2000). Regulation of serotonin release by GABA and excitatory amino acids. Journal of Psychopharmacology, 14(2), 100-113. doi: 10.1177/ 0269881100014 00201.

Thompson, T.L. \& Moss, R.L. (1997). Modulation of mesolimbic dopaminergic activity over the rat estrous cycle. Neuroscience Letters, 229(3), 145-8. doi: 10.1016/S0304-3940(97)00450-3.

Torner, L., Toschi, N., Neva, G., Clapp, C., \& Neumann, I.D. (2002). Increased hypothalamic expression of prolactin in lactation: Involvement in behavioural and neuroendocrine stress response. European Journal of Neuroscience,
15, 1381-1389. doi:10.1046/j.1460-9568.2002. 01965.x.

Torner, L., Toschi, N., Pohlinger, A., Landgraf, R., \& Neumann, I.D. (2001). Anxiolytic and antistress effects of brain prolactin: improved efficacy of antisense targeting of the prolactin receptor by molecular modeling. The Journal of Neuroscience, 21(9), 3207-3214. Retrieved April 5 2012, from http://www.jneurosci.org/ content/ 21/9/3207.full.

Tóth, Z.E., Zelena, D., Mergl, Z., Kirilly, E., Várnai, P., Mezey, E., Makara, G.B., \& Palkovits, M. (2008). Chronic repeated restraint stress increases prolactin-releasing peptide/tyrosine-hydroxylase ration with genderrelated differences in the rat brain. Journal of Neurochemistry, 104(3), 653-666. doi:10.1111 j.1471-4159.2007.05069.x.

Toufexis, D.J., Myers, K.M., Bowser, M.E., \& Davis, M. (2007). Estrogen disrupts the inhibition of fear in female rats, possibly through the antagonistic effects of estrogen receptor $\alpha$ $(\mathrm{ER} \alpha)$ and ER $\beta$. Journal of Neuroscience, 27(36), 9729-9735. doi: 10.1523/JNEUROS CI.2529-07.2007.

Walf, A.A. \& Frye, C.A. (2005). Antianxiety and antidepressive behavior produced by physiological estradiol regimen may be modulated by Hypothalamic-Pituitary-Adrenal axis activity. Neuropsychopharmacology, 30, 1288-1301. doi: 10.1038/sj.npp.1300708. 
